\title{
ABSTRAK \\ PENGEMBANGAN MATERI BAHASA UNTUK MENINGKATKAN KEMAMPUAN MEMBACA TEKS DIKALANGAN MAHASISWA FAKULTAS ILMU TARBIYAH DAN KEGURUAN IAIN AMBON
}

\section{Faqih Seknum, Tenaga Pengajar Program Pascasarjana IAIN Ambon, dan Program Pascasarjana Bahasa Inggris Universitas Pattimura Ambon, Jl. Dr. Tarmizi Taher, 082220815440, E-mail: anggifaqih@ rocketmail.com}

English is one of International Language and as Communication with other in the world. In Indonesia the level of education from SD until University learning English as a Foreign language but is not second language. The Faculty of Tarbiyah and Education IAIN Ambon. The writer research about the ability the students for three department were Biology, Mathematics and PAI for the ability reading English text, the result from questioner and test showed that the ability from student all specially Biology, mathematics and PAI department still lower. The result from comprehension reading text and ability to answering the question still problem. The find result from research can be found differences between the first test the students get result $64,13 \%$ where the student still understanding about the question and reading text, but from second test for all students result $50,06 \%$ this is indicate that the ability from student follow the lower when developing classroom materials we should also consider principles of language teaching. Some of the teaching principles is the teaching should meet the needs and want of the learners. The lectures always to looking for other method and strategy to develop students ability in reading text in English.

Key words: reading, more is important, students.

Bahasa Inggris sebagai bahasa Internasional yang penutur paling banyak di dunia jika dibandingkan dengan bahasa asing lain yang ada di dunia. Di Indonesia Bahasa Inggris dapat diterapkan mulai dari Sekolah Dasar (SD) sampai Perguruan Tinggi. Bahasa Inggris dalam konteks Indonesia adalah sebagai bahasa asing atau EFL, bukan sebagai bahasa kedua (second language) atau EFL. Mata kuliah yang diajarkan di Fakultas Tarbiyah IAIN Ambon, khususnya mata kuliah Bahasa Inggris yang dianggap sebagai 
MKDU sejak lama diajarkan di kalangan mahasiswa Fakultas Tarbiyah IAIN Ambon. Hal ini menyimpan beberapa permasalahan pokok yang ada di Kampus IAIN Ambon antara lain: pertama adalah dikarenakan para mahasiswa menganggap bahwa mata kuliah Bahasa Inggris sebagai MKDU saja, permasalahan yeng kedua karena kurang minatnya/interest mahasiswa terhadap Bahasa Inggris, ketiga rata-rata mahasiswa mengalami kesuliatan yang kompleks terhadap empat kompoetensi dalam Bahasa Inggris yakni kompetensi writing, speaking, listening dan reading dan yang keempat adalah belum ada minat mahasiswa dalam membaca teks-teks Bahasa Inggris.

Permasalahan yang dialami di lokasi penelitian adalah adanya mayoritas mahasiswa tidak dapat membaca teks-teks Bahasa Inggris dengan baik dan benar, kesulitan ini bukan saja terletak pada cara ucapan/membaca akan tetapi sering banyak dialami oleh sulitnya mahasiswa memahami isi teks yang dibaca. Selain itu menurut pandangan Y. Goodman (1975 dalam Robert J. Tierney at al. 1995:460) memberikan penekanan terhadap membaca seperti berikut:

These raders use effective reading strategies when the material is higly interesting to them or when it is easy because it has a low concept load. Howerver,when these readers find themselves reading material which is complex, they use less efficient reading strategies. They stop searchig for meaning and end up sounding out or word calling. When asked how handle any particular raeding problem, such readers often say the sound words out; they may be unaware that they use context to read or they may believe the teacher disapproves of it. Strategy lessons help these readers become aware of the various effecitive reading strategies they already use when reading easy material permatting them to transfer effective reading strategies to more difficult reading materials.

Pendapat diatas, menggambarkan bahwa bilamana seseorang yang melaksanakan membaca secara efektif dan baik tergantung bahan teks yang dibaca memilki kualitas yang tinggi hal ini dapat memperngaruhi semangat membaca seseorang. Sebaliknya jika dalam konteks bacaan terdapat level bacaanya rendah maka dengan sendirinya dapat diucapkan dengan mudah. meskipun demikian seseorang membaca akan sulit menemukan konsep sesuai dengan bacaan secara lengkap. Penggunaan strategi membaca merupakan hal yang efisien dalam menyesuaikan sebuah 
teks bacaan. Dengan menggunakan ragam bunyi atau intonasi yang diucapkan melalui kata-kata selaian itu ada bebrapa persolan penting yang digunakan sebagai solusi pemecahan masalah terkait dengan berbagai persoalan yang muncul dalam konteks pembelajaran mermbaca itu sendiri. Untuk memecahkan berbagai problem membaca mahasiswa khususnya di Fakultas Tarbiyah IAIN ambon, maka perlu pendekatan dosen secara khusus dalam kegiatan membaca. Strategi yang digunakan dapat membantu bentuk efektif membaca pada materi dengan efektif dengan strategi lebih banyak kesulitan melalui membaca.

\section{METODE PENELITIAN}

Penelitian ini merupakan Metode Penelitian kombinasi atau mixed metode yang merupakan pendekatan penelitian yang mengkombinasikan atau mengasosiasikan bentuk kualitatif dan bentuk kuantitatif, pendekatan ini melibatkan asumsi-asumsi filosofis, aplikasi. Pendekatan-pendekatan kualitatif penampilan mixing (Cresswell dan Plano Clark, 2007) . sejalan dengan kerangka teoritis dan hasil-hasil yang relevan, variable yang diteliti mencakup (jenis bahan ajar berdasarkan bacaan level mudah, sedang, dan sulit, selain itu faktor kemampuan mahasiswa dalam membaca teks-teks Bahasa Inggris serta faktor lain yang mempengaruhi mahasiswa.

\section{Lokasi Penelitian}

Penelitian ini dilaksanakan di tiga Jurusan yakni pendidikan Biologi, Matematika dan PAI yang ada di FAkultas Tarbiyah IAIN Ambon.

\section{Subjek Penelitian.}

Subjek penelitian ini diambil Mahasiswa dari ketiga Jurusan yang Jumlahnya sebaanyaak 8 kelas seperti telihat pada Tabel 1.1.

Tabel 1.1. Jumlah Mahasiswa Tiga Jurusan.

\begin{tabular}{|l|l|c|c|}
\hline No & Jurusan & Jumlah Kelas & Jumlah Mahasiswa \\
\hline 1 & Biologi & 5 & 200 \\
\hline 2. & Matematika & 4 & 150 \\
\hline 3. & P A I & 3 & 110 \\
\hline & \multicolumn{2}{|r|}{ Jumlah } & $\mathbf{4 6 0}$ \\
\hline
\end{tabular}

Dari total mahasiswa pada tiga jurusan sebanyak 460 yang terdiri dari masingmasing Pendidikan Biologi 200 orang, Pendidikan Matematika 150 orang dan PAI 110 
orang. Dari total mahasiswa yang ada, penulis menggunakan 10 sampai 20 persen Sebagai Sampel.

\section{Instrument Penelitian.}

Instrument penelitian yang dikembangkan mencakup (1) angket guna sebagai awal gambaran kompetensi mahasiswa terhadap mata kuliah Bahasa Inggris, (2) tes, untuk mengetahui seberapa kemaampuan mahasiswa dalam membaca teks-teks Bahasa Inggris, dan (3) dokumen. Angket menurut Sukmadinata (2008: 219) angkaet atau kuesioner merupakan satu teknik atau cara pengumpulan data secara tidak langsung. Teknik angket digunakan untuk memperoleh data tentang tanggapan atau pendapat mahasiswa tentang modelo perkuliahan Bahasa Inggris yang ada di Lingkungan Fakultas Tarbiyah, khussunya di tiga jurusan yang diambil sebagai objek penelitian, selain itu dalam rangka memperoleh data tentang permasalahan mahasiswa pada saat perkuliahan mata kuliah Bahasa Inggris (khususnya membaca teks-teks Bahasa Inggris).

\section{Analisais Data.}

Analisis deskreptif digunakan untuk mendapatkan gambaran awal perkuliahan Bahasa Inggris ( Materi tentang membaca teks-teks Bahasa Inggris) analisis kualitatif terhadap data yang diperoleh melalui angket untuk mengidentifikasi belajar mahasiswa di kelas dan analisis kuantitatif diterapkan agar mengidentifikasi perkembangan kemampuan membaca terks-terks Bahasa Inggris oleh mahasiswa di lokasi penelitan.

\section{HASIL DAN PEMBAHASAN}

Hasil angket yang dilakukan pada tanggal 5-6 Juli 2013 untuk 8 kelas yang diambil ketiga jurusan yakni: Biologi, Matemetika dan PAI. Dari sepulu pertanyaan yang diajukan ke mahasiswa pertanyaan itu mengandung minat, kompotensi, serta lainlain yang diidentifikasi motivasi mahasiswa sendiri dan juga pengaruh lingkungan belajar. Mahasiswa memberikan tanggapan yang berfariasi antara lain: pertanyaan momor 1 menurut mereka mata kuliah Bahasa Inggris Menyenangkan 45\% dan pertanyaan nomor 2 tentang kompetensi reading penting bagi mereka merespon dengan $34 \%$ pertanyaan nomor 3 terkait dengan memahami kandungan teks bacaaan sebanyak $40 \%$ dan pertanyaan nomor 4 , kompetensi membaca dirasakan sukar untuk dipahami 
$32 \%$ dan pertanyaan nomor 5 pengaruh dosen dalam meningkatkan membaca hanya mencapai $38 \%$ dan pertanyaan nomor 6 , metode membaca yang baik untuk dipahami dengan cara reading comprehension $60 \%$ dan pertanyaan nomor 7 , tentang ketrampilan mana yang paling disukai mahasiswa mereka merespon sebanyak $60 \%$ lebih suka speaking dan pertanyaan nomor 8 , metode mengajar dosen yang sudah sesuai teks-teks Bahasa Inggris sebanyak $42 \%$ dan pertanyaan nomor 9, berhubungan dengan teks-teks bacaan yang diberikan dosen selama ini mahasiswa sebanyak $63 \%$ menjawab sudah sesuai kompetensi reading. Dan pertanyaan nomor 10. Terkait dengan kemampuan membaca mahahasiswa ternayata meraka menjawab dengan sebanyak $39 \%$ menjawab adanaya pengaruh dosen, usaha sendiri dan pengaruh buku dan teks-teks Bahasa Inggris.

Seebelum diadakan test tertulis pada mahasiswa dalam penelitian ini terlebih dahulu diberikan angket/questioner untuk melihat obyektifitas mahasiswa terhadap apa yang dialami selama ini di kampus, hasil questioner sebagaimana tergambar diatas selanjutnya Peneliti mengadakan test kepada mahasiswa sebanyak 2 kali dengan teks dan soal yang berbeda untuk melihat kemampuan kognitif mahasiswa yang ada pada 3 jurusan

Tabel 1.2. Tabel hasil test 1 Jurusan: BIOLOGI, MATEMATIKA \& PAI.

\begin{tabular}{|c|c|c|c|c|}
\hline $\begin{array}{c}\text { Nomor } \\
\text { Item }\end{array}$ & $\begin{array}{c}\text { Jumlah } \\
\text { Mahasiswa }\end{array}$ & Tes 1/Skors & Penguasaan \% & Perolehan \\
\hline 1 & 87 & 56 & $64,36 \%$ & Sign \\
\hline 2 & 87 & 44 & $50,57 \%$ & Sign \\
\hline 3 & 87 & 23 & $26,43 \%$ & Unsign \\
\hline 4 & 87 & 30 & $34,42 \%$ & Unsign \\
\hline 5 & 87 & 47 & $52,02 \%$ & Sign \\
\hline & \multicolumn{2}{|c|}{ J u m l a h } & $64,13 \%$ & \\
\hline
\end{tabular}

Dari hasil tes bagian (pertama) yang diberikan pada 87 mahasiswa untuk ketiga jurusan seperti dalam tabel tersebut, masing-masing dapat diinterpretasi sebagai berikut. Hasil analisis soal no 1, terdapat 56 atau (64\%) mahasiswa dapat memahami isi teks dan menjawab benar secara mayoritas. Hal ini menunjukkan bahwa mahasiswa paham terhadap apa yang meraka membaca dalam teks dimaksud.Soal nomor 2 sebanyak 44 mahasiswa (50.57\%) menjawab soal tersebut dengan benar, hal ini menunjukkan bahwa mahasiswa masih mengerti apa yang mereka baca dari teks tersebut. Sementara pada 
soal no 3, terdapat 23 orang mahasiswa (26.43\%) mahasiswa mengalami kesulitan dalam memahami isi teks maupun menjawab soal yang ada, hal ini menunjukkan bahwa teks yang dibaca lebih sulit dan tidak dikuasai sebagaiman yang diharapkan. Sementara soal nomor 4 , terdapat $30(34.42 \%)$ mahasiswa mengalami kesulitan untuk menjawab dengan baik dan sempurna ini menunjukan bahwa tingkat kemampuan mahasiswa dalam memahami isi teks tersebut belum baik. Sementara soal 5 terdapat $47(54.02 \%)$ mahasiswa bisa menjawab dengan baik dan benar. Dari hasil yag diberikan pada soal no 5, menunjukkan bahwa secara signifikan mahasiswa masih memahami isi teks yang dibaca.

Dari permasalahan yang tergambar dari hasil tes bagian pertama menunjukan bahwa mahasiswa dari ketiga jurusan tersebut, secara signifikan memahami isi kandungan apa yang ada dalam teks tersebut dengan baik. Hal ini terbukti adanya terdapat $60 \%$ menunjukkan kemampuan mahasiswa dalam memahami isi teks tersebut dengan baik dan benar selain itu untuk melihat hasil membaca dikangan mahasiswa pada teks kedua dapat diuraikan sebagai berikut dibawah ini.

Tabel 1.3. Tabel hasil tes II Jurusan: BIOLOGI, MATEMATIKA DAN PAI.

\begin{tabular}{|c|c|c|c|c|}
\hline Nomor Item & $\begin{array}{c}\text { Jumlah } \\
\text { mahasiswa }\end{array}$ & Tes II/Skors & Penguasaan \% & Perolehan \\
\hline 1 & 87 & 48 & $55.17 \%$ & Signifikan \\
\hline 2 & 87 & 27 & $31 \%$ & Unsignifikan \\
\hline 3 & 87 & 35 & $40.22 \%$ & Unsignifikan \\
\hline 4 & 87 & 40 & $45.95 \%$ & Signifikan \\
\hline 5 & 87 & 27 & $31,03 \%$ & Unsignifikan \\
\hline 6 & 87 & 46 & $52.87 \%$ & Signifikan \\
\hline 7 & 87 & 36 & $41.37 \%$ & Unsignifikan \\
\hline 8 & 87 & 29 & $33,33 \%$ & Unsignifikan \\
\hline 9 & 87 & 16 & $18.39 \%$ & Unsignifikan \\
\hline 10 & 87 & 46 & $52,87 \%$ & Signifikan \\
\hline & & & $440.33 / 87$ & \\
\hline & & & 50.06 (Result) & \\
\hline
\end{tabular}

Berdasarkan hasil tes ke 2 dari 87 mahasiswa yang terdiri dari 3 Jurusan seperti termuat dalam tabel diatas, dilihat sebagai berikut: pada soal no 1, mahasiswa dapat menjawab benar mencapai 48 (55.15\%) menunjukkan mayoritas mahasiswa masih memahami isi teks yang dibacanya.sementara pada item soal nomor 2, mahasiswa dapat 
menjawab benar sebanyak 27 (31\%) hal ini menunjukkan adanya belum sepenuhnya penguasaan terhadap teks yang dibacanya. Dan untuk pertanyaan nomor 3, secara mahasiswa sebanyak 35 (40,22\%) ini menandakan bahwa teks/soal masih sulit. Dan sementara pada soal nomor 4 , terdapat $40(45,95 \%)$ orang mahasiswa menjawab dengan baik dan benar . untuk soal nomor 5 kemampuan menjawab benar hanya 27 (31,03\%) yang mahasiswa menjawab benar. Soal nomor 6, Terdapat $46(52,87 \%)$ mahasiswa menjawab benar. Soal nomor 7, sebanyak 36 (41,3\%) mahasiswa menjawab benar, hal ini menunjukan bahwa mahasiswa secara mayoritas tidak memahami isi teks bacaaan dimaksaud. Sementara nomor 8, terdapat 29 (33,33\%) yaqng dapat menjawab peretanyaan tersebut dengan baik dan benar. sementara soal nomor 9, terdapat 16 $(18,39 \%)$ mahasiswa menjawab soal dengan tepat. Unutk nomor 10, terdapat46 $(52,87 \%)$ mahasiswa menjawab dengan benar.

Dari perolehan hasil baik dari hasil angket maupun melalui hasil belajar yang dibuktikan dengan pemberian tes 1 dan 2 untuk kemampuan real mahasiswa di kalangan Fakulktas Tarbiyah IAIN Ambon. Menunjukkkan adanya belum berhasilnya proses perkuliahan di IAIN Ambon khsusnya mata kuliah Bahasa Inggris yang berorientasi pada kompoetensi membaca dan atau pemahaman bacaaan teks-teks bahasa Iggrias di kalangan mahasiswa. Menurut Abdurrahman (2003) prestasi belajar dipengaruhi dua faktor yakni faktor internal dan faktor eksternal. Faktor eksternal yang kemungkinan adanya fungsi neurologi, sedangkan faktor eksternal, yaitu antara lain berupa strategi perkuliahan/belajaran yang keliru, pengelolaan kegiatan belajar yang tidak membangkitkan motivasi belajar mahasisw/siswa. Dan faktor-faktor neorologi antara lain : faktor, genetic, luka pada otak, pencemaqranb lingkungan/kekuatan oksigen, faktor biokimia, gizi yang tidk memadai dan faktor pengaruh psikiologi dan social yang merugikan mahasiswa. Sementara hal yang sama disimpulkan oleh Djamarah (2002: 2001) mengelompokqan kedalam dua kategori, yaitu faktor internaldan faktor ekternal tentang sebab-sebab kurang lancarnya membaca. Faktor internal adalah faktor penyebab yang berasal dari dalam diri anak itu sendiri. Penyebab yang muncul dalam diri antara lain biasa bersifat: Kognitif (ranah cipta), seperti rendahnya kapasitas intelektual anak; 
Afektif (Rana Rasa), seperti labilnya emosi dan sikap; dan Psikomotor (Ranah Karsa), seperti terganggunya alat-alat indera penglihatan, dan pendengaran (mata dan telinga)

Kurang lancarnya membaca secara khusus dikatakan Abdurrahman (1999: 2006) akan menjadi faktor penghambat dalam kegiatan membaca. Hal ini disebabkan sebagai berikut: (a) mahasiswa kurang mengenal huruf, bunyi bahasa (fonetik), dan bentuk kalimat, (b) mahasiswa tidak memahami makna kata yang dibaca, (c) adanya perbedaan dialeg atau pengucapan antara mereka secara fundamental (d) mahasiswa terlalu cepat membaca karena kemungkinan perasaanya tertekan, (e) mereka bingung meletakan posisi kata yang diucapkannya (f) bingung dengan membaca huruf yang bunyinya sama seperti : bunyi huruf $/ \mathrm{b} / \mathrm{dan} / \mathrm{p} /(\mathrm{g})$ anak kurang mengerti tentang arti tanda baca, maka tanda baca tidak perlu diperhatikannya (h) Terjadinya keragu-raguan dalam membaca.

Faktor eksternal adalah faktor yang berasal dari luar, yang meliputi semua situasi dan kondisi lingkungan sekitar yang tidak mendukung aktifitas belajar anak, faktor lingkungannya meliputi: Lingkungan keluarga, contohnya orang tua tidak pernah mendampingi dan membimbing anak waktu belajar; Lingkungan perkampungan atau masyarakat, contohnya wilayah perkampungan kumuh (slum area) dan teman sepermainan (peer group) yang nakal; dan Lingkungan sekolah, contohnya kondisi dan letak gedung sekolah yang buruk, dekat pasar, kondisi guru, serta kurangnya peralatan untuk kepentingan pembelajaran.

Membaca adalah aktivitas pencarian informasi melalui lambing-lambang tertulis. Membaca adalah suatu proses bernalar, Reading is reasoning. Dengan membaca kita mencoba mendapatkan dan memproses informasi hingga mengendap menjadi sebuah pengetahuan. Dan pengetahuan itu sendiri akhirnya menjadi suatu dasar untuk dinamisasi kehidupan, memperlihatkan eksistensi, berjuang mempertahankan hidup, dan mengembangkan dalam bentuk sains dan teknologi sebagai kebutuhan hidup manusia.

Secar umunya perkuliahan Bahasa Inggris yang dilaksanakan di kampus IAIN Ambon khususnya Fakultas Tarbiyah dan Ilmu Pendidikan dari segi konteksinalnya sudah berlangsung dengan baik dan lancer, akan tetapi beberapa permasalahan yang mendasar dari lemahnya penguasaan mahasiswa terhadap membaca teks-teks Bahasa Inggris disebabkan karena: Kelemahan dan Ketidak mampuan mahasiswa terhadap 
membaca teks-teks Bahasa Inggris bermula dari tamatan SMA/MA. Yang tidak menguasai car abaca teks-teks Bahasa Inggris; Minat dan kemampuan mahasiswa yang masih rendah dan belum baik terhadasp mata kuliah Bahasa Inggris; dan Waktu perkuliahan Bahasa Inggris yang masih kurang dan sedikit sehingga tidak memberikan ruang dan waktu pada pembelajaran mahasiswa di kampus lebih banyak; serta Rata-rata dosen yang mengajarkan Mata Kuliah Bahasa Inggris tidak berfokus pada suatu kompetensi saja misalnya kompetensi reading atau membaca yang masih dirasakan mahasiswa sangat kurang dan jarang di kelas.

Menurut Graves (2001) menyarankan untuk beberapa hal penting yang diikuti dalam aktivitas membaca teks-teks Bahasa Inggris. Prinsip pembelajaran membaca teksteks Bahasa Inggris dianjurkan untuk mengikuti beberapa saran atau poin yang dibuat. Yang pertama dosen memberikan arahan atau permasalahan utama dari tujuan membaca, yang kedua memotivasi mahasiswa dalam kompetensi membaca dan ketiga, diberikan pembendarahan kata dan konsep teks pembelajaran yang tepat, keempat melihat dan perlu mengetahui latar belakang mahasiswa terhadap pengetahuan dasar yang dimiliki kelima, korelasi bahan bacaan mahasiswa dengan apa yang dipelajari dan yang terakhir adalah bangun kemampuan dan pengetahuan mahasiswa terhadap teksteks bacaan yang ada.

\section{KESIMPULAN}

1. Secar mayoritas mahasiswa masih mempunyai keinginan dalam belajar Bahasa Inggris yang perlu dikembangkan selanjutnya oleh Dosen Bahasa Inggris

2. Mahsiswa secara mayoritas lebih menyukai belajar kompetensi Speaking dari pada kompetens Reading atau membaca

3. Kesulitan mahasiswa secara total berada pada membaca teks-teks Bahasa Inggris

4. Hasil tes yang diberikan pada mahasiswa dari Ketiga Jurusan dimana hasil Pertama menunjukan adanya tingkat penguasaan membaca dan menjawab soal terhadap teks dari teks pertama masih positif dengan hasil secara keseluruhan berkisar $64.13 \%$ artinya kemampuan mahasiswa agak seimbang dengan soal yang dberikan, sementara pada teks Kedua menunjukan adanya mahasiswa mengalami kesulitan 
memahami isi teks yang dibacanya dan sekaligus menjawab pertanyaan hasilnya berkisar pada 50.06\%, (Result) dari total hasil tes pertma dan kedua dari Ketiga Jurusan menunjukan adanya faktor membaca mahasiswa belum maksimal atau secra mayoritas mahasiswa tidak memahami isi teks serta sulit menjawab pertanyaan yang diajukan oleh Penulis.

\section{SARAN}

1. Dosen lebih banyak memberikan waktu yang banyak serta motivasi yang tinggi kepada mahasiswa banyak membaca teks-teks Bahasa Inggris

2. Pengenalan membaca dikalangan mahasiswa terhadap teks-teks Bhasa Inggris perlu di prioritaskan

3. Semua pihak harus kerja sama untuk meningkatkan kualiatas Perkuliahan khususnya Mta Kuliah Bahasa Inggris di Fakultas Tarbiyah IAIN Ambon.

\section{DAFTAR PUSTAKA}

Abdurrahman. 1999. Strategi Membaca Teori Dan Praktek CV Andira. Bandung

Alwasilah A. Chaedar. 2004. Perspektif Pendidikan Bahasa Inggrios Di Indonesia Dalam Konteks Persaingan Global Angkasa. Bandung

Creswell .2007. qualitative Inquiri And Research Design: Choosing Among Five Approach ( $2^{\text {nd }}$ ed). Thousand Oaksa. CA Sage

Creswell W. John .2010. Research Design Pendekatan Kualitatif Kuantitatif. dan Mixed thouseh. Oaks California 91320.

Sukmadinata, Nana Syaodih. 1995. Metode Penelitian Pendidikan. Remaja Rosdakarya. Bandung

Tierney J. Robert et al .1995. Reading Strategies And Practices A Compendium fourt Edition. The Ohio state Univeristy.

http://en.wikipedia.org/wiki/Reading Comprehension. 